\title{
Development of Moodle Application on the Subject of Fungi as a Biological Learning Resource for High School Students
}

\author{
Erika Arifiana $^{1}$, Imam Mudakir ${ }^{1}$, Mochammad Iqbal ${ }^{1}$ \\ Education Sciences, the Faculty of Education, University of Jember \\ Jl. Kalimantan 37, Jember 68121 \\ e-mail: imam_mudakir@yahoo.com
}

\begin{abstract}
This study aimed to develop a web-based learning materials using Moodle Application. This was a Research and Development study. The data were collected using needs analysis questionnaire, pre-test/post-test, student responses questionnaire, and experts validation. The development process was carried out using ADDIE model (Analyze, Development, Design, Implemantation, Evaluation). The result showed that all expert judgments were on satisfaction category. The content expert gave 80,23\%, the learning media expert gave 80,7\%, while the development expert agree in the point of $75 \%$ and teacher as user prospectus gave agreement on $80 \%$.
\end{abstract}

Keywords: Teaching Materials, Moodle application, ADDIE

\section{INTRODUCTION}

The development of science and technology has brought a change in almost every aspect of human life. The era of globalization has affected the progress of communication technology. Competition on human globalization knows no boundaries, so the demand for quality human resources who are able to play a role in the development of communication technology has become a necessity. In order to improve the quality of human resources, education holds a very important role in the process of improving the quality of human resources. The responsibility of schools regarding the era of globalization has been to prepare students to face all the challenges that are rapidly changing in our society (Ketut, I. 2016)..

School is required to produce a good quality of human resources who are able to compete in this global competition. Improving the quality and ability of students can be done by utilizing the Internet as an area to access the widest possible knowledge. This can be done by incorporating ICT as an approach in the learning process at the Institute of Education.

The Ministry of Education and Culture Services has several programs that are useful for improving the quality of students and schools in the use of ICT
(Information and Communication Technology).

ICT is able to provide a positive contribution in promoting the development of science and technology, so the quality of ICT in schools needs to be improved (Herayanti, 2015). Student achievement is determined by teacher's strategy such as appropriate approaches and methods to deliver the subject matter as well as the learning tools used in the teaching and learning process. Using ICT-based teaching materials or learning resource in high school plays an important role in attracting student interest and in improving the quality of student learning.

One factor affecting the quality of education is teachers. Teachers are a central point in the renewal and improvement of the quality of education (Widi, 2015).

The preliminary need analysis showed that the concept of Fungi was one of abstract concepts in Biology, this concept was also rarely accomodated into learning media or learning tools.

It is necessary to complement learning activity with appropriate learning media or learning tool to enhance student understanding. Learning media serves as a tool to transfer the message in the form of knowledge from the teacher to the learner (Anjarwati, et.al,. 2016). A survey on teachers revealed that there had never been 
any development of web-based teaching materials. Teachers usually use powerpoint or video. Teachers has also never done online teaching for students. The developed Moddle serve as sufficient initiative to start online style of teaching.

Moodle application is an effective tool providing facilities with important features to support learning such as assignments, quizzes, chat, and collaboration. The main feature is downloadable formats of shared materials whether its images, files or videos. Moodle is very easy for students and teachers to interact outside of school hours, teachers can monitor student activity through these devices, students can also easily communicate with teachers through these devices if there is material that is still not understood because these devices have features of Moodle chat (Anjarwati, 2016).

Moodle is a name for an application program that can transform an instructional media into a web form. This application allows students to get into the "digital classroom" to access the learning materials, quizzes, or other. With this, concept of teaching and learning system will not be limited to space and time. A primary teacher can provide learning materials from anywhere. A student can also follow the learning activities anywhere (irianti, et.al., 2017).

Therefore, the author aimed to develop web-based teaching materials with the title of "Fungi Instructional Materials Development of Web-Based Applications Using Moodle for High School Biology Education".

\section{RESEARCH METHODS}

This $\mathrm{R}$ and $\mathrm{D}$ study used the model development of ADDIE (Analyze, Design, Implementation, and Evaluation). Thos model serve as guidelines in building training programs or learning effectiveness. It comes in several stages (Herayanti and Habibi, 2017).

\section{a. Research procedure}

1. Analyze; the analysis of students and teachers characteristics, curriculum and learning objectives.

2. Design; the design of assessment instruments, and media selection.

3. Development; the production of materials and proceed with the validation assessment by experts.

4. Implementation; the implementation of the learning system, the product has been created and has been through revision stage.

5. Evaluation; to see whether the system is successfully applied.

\section{b. Data collection technique}

Data collected by distributing a questionnaire to students and teachers, assessment by experts and followed by a test that consists of pre-test and post-test.

\section{c. Data analysis}

Data were analyzed using descriptive qualitative method. Data of validity consist of content validation, media validation, learning expert validation, and users. Percentage of validity can be obtained from the following formula.

$$
\mathrm{P}=\frac{\sum X i}{\sum^{Y i}} \times 100 \%
$$

Information:

$\mathrm{P}$ : The percentage of total votes

$\sum x$ : The number of scores obtained for all aspects of $\mathrm{i}$

$\sum Y$ : The number of maximum scores to aspects of $\mathrm{i}$

$$
\text { i: } 1,2,3, \ldots \ldots ., \mathrm{N}
$$

Percentage of media validity criteria can be seen in Table C.1.

\begin{tabular}{ccl}
\hline $\begin{array}{c}\text { Scale } \\
\text { Value } \\
\text { validity }\end{array}$ & Criteria & \multicolumn{1}{c}{ Information } \\
\hline $76 \%-$ & very & $\begin{array}{l}\text { New product ready to be } \\
\text { used in the actual field of } \\
\text { learning activities }\end{array}$ \\
\hline $100 \%$ & valid & $\begin{array}{l}\text { Products can be followed } \\
\text { by adding something } \\
\text { less, perform certain } \\
\text { considerations, which do }\end{array}$ \\
\hline
\end{tabular}




\begin{tabular}{ccl}
\hline $\begin{array}{c}\text { Scale } \\
\text { Value } \\
\text { validity }\end{array}$ & Criteria & \multicolumn{1}{c}{ Information } \\
\hline & & $\begin{array}{l}\text { not increase too much } \\
\text { and not fundamentally }\end{array}$ \\
\hline $26 \%-$ & less & $\begin{array}{l}\text { Revise to re-examine } \\
\text { carefully and look for } \\
\text { weaknesses for refined } \\
\text { products }\end{array}$ \\
\hline$\leq 25 \%$ & valid & $\begin{array}{l}\text { Massively revise the } \\
\text { contents of the product }\end{array}$ \\
\hline
\end{tabular}

(adopted from Fitriani and Musri, 2016).

\section{RESULTS AND DISCUSSION}

\section{Analyze}

This stage of the data collection activities analyze three aspects of the learning process, learning materials, and teaching materials used.

A questionnaire was distribute to students and teachers at SMAN 1 and SMAN 1 Purwoharjo Muncar .The data generated from this phase was qualitative data regarding the use of learning media and learning souce, especially in the concept of Fungi.

The results at this stage earned some criticism and feedback from students and teachers related to the media developed. Some students argue that the media used is quite varied, such as textbooks, worksheets, videos, and ppt, only a few students feel bored and need a variety of instructional media for the learning process more fun. Some teachers and students agree that webbased teaching materials will have great support in enhancing teaching and learning.

\section{Design}

This phase was done with the preparation of the media framework, systematic determination, and preparation of product assessment instruments. The media framework was the material adapted in the Moodle application. Inside this application, a video was tailored to section the material that will be taught. As examples of the preliminary design of media can be seen in Figure 1 and Figure 2.

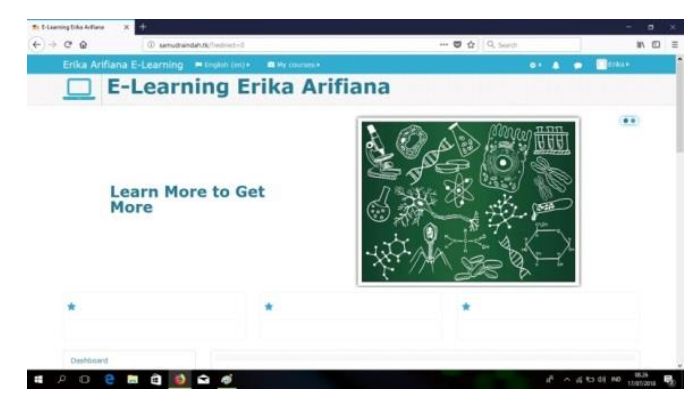

Figure 1. The initial view of the application Moodle

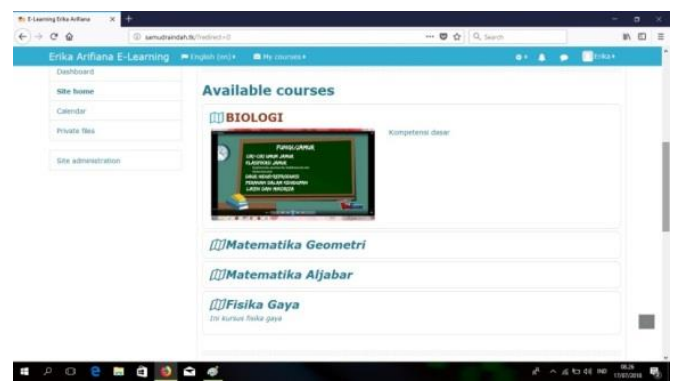

Figure 2. Make material available in Moodle application

\section{Development}

This phase was done with the preparation of instructional media, the experts assessment, and the revision of the media.

In preparation of instructional media, the results were a video contain the general characteristics of fungi and classification Fungi (examples, reproduction, and the role of life were included). Next was the assessment of product through expert validation. Validation is a stage to locate and determine the things that still need to be improved or revised so that the product is more effective and efficient (Puji, et.al., 2014). The results of product revision can be seen in Figure a and Figure b.

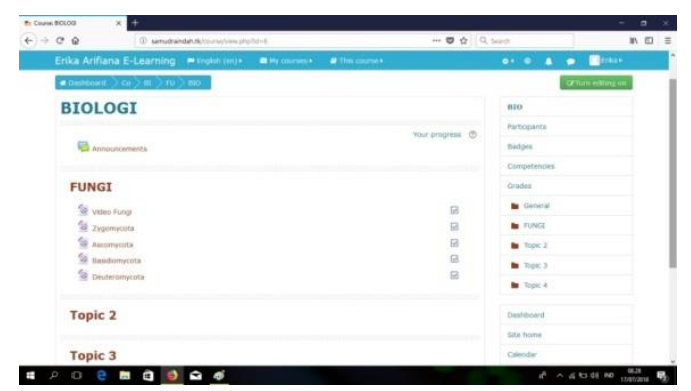


Figure a. Display section of Fungal material in Moodle application

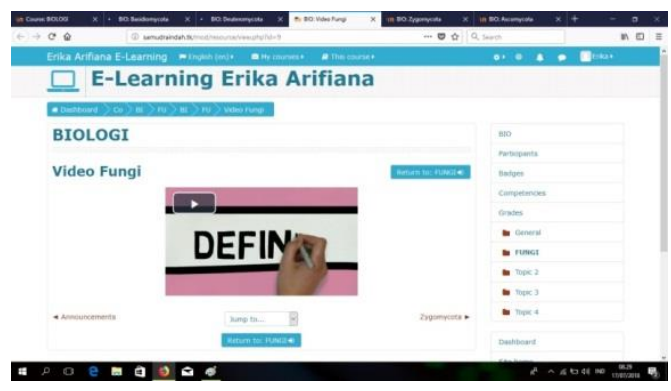

Figure b. Video display in the Moodle application

Validation of web-based teaching materials (Moodle) was done before its implementation. Validation is done by media experts, content expert, learning expert as well as users. Here are the results of the validation.

Table 1. Assessment Validation of Experts

\begin{tabular}{|c|c|c|c|}
\hline No. & validator & $\begin{array}{l}\text { Rate } \\
(\%)\end{array}$ & Category \\
\hline 1 & $\begin{array}{l}\text { expert } \\
\text { Content }\end{array}$ & 85.25 & $\begin{array}{c}\text { very } \\
\text { Valid }\end{array}$ \\
\hline 2 & expert Media & 80.7 & $\begin{array}{c}\text { very } \\
\text { Valid }\end{array}$ \\
\hline 3 & $\begin{array}{l}\text { Learning } \\
\text { expert }\end{array}$ & 75 & valid \\
\hline 4 & $\begin{array}{l}\text { users } \\
\text { teacher } 1\end{array}$ & 80 & $\begin{array}{l}\text { very } \\
\text { Valid }\end{array}$ \\
\hline & Average & 80.23 & valid \\
\hline
\end{tabular}

Based on the table, all validity result falls into valid and very valid category with the persentage range from 75 to 85 . Content that relates to competence and indicators is expected to encourage students to find their concept attainment independently. Aspects of the material/content is generally assessed based on its relevance to the curriculum, the relevance of the material with the purpose of learning, truth in terms of linguistics and humanities, as well as compliance with the students' cognitive development (Matondang, 2009).

There were 3 aspects measured media experts validation, those were easyness of navigation, visual communication, and overall function. The result showed that the Moodle application was easy to operate for users. As for learning expert validation instrument, there were 4 criterion namely delivery techniques, supporting material presentation, learning delivery, and delivery components. The result showed that the use of moodle was in accordance with the learning system in the classroom. Three aspects were present for teacher as potential users of the developed Moodle. Those were the content, suitability of learning objectives with the Basic Competences, and the student's need. The content, the learning objectives must be in accordance with Basic Competence. Media can be used as an additional tool that can provide new insights to users, especially students (Hanifah, 2014).

\section{Impelementation}

This phase was done by applying the post-revision product. All that has been developed, then being installed in such a manner in accordance with the roles and functions. The implementation were done in SMAN 1 and SMAN 1 Purwoharjo Muncar.

This stage was carried out to determine the readability test, the level of difficulty and the practicality of Moodle. The practicality was determined by questionnaire's data obtained from teachers and students. The effectiveness of Moodle by comparing the pre-test and post-test scores. The result of legibility and difficulty test both gained satisfactory agreement in the very valid category. That meant the Moodle was applicable in classroom.

Practicality test aimed to determine the extent of convenience and adherence to the development of web-based teaching materials using Moodle. Practical learning media is determined by the easyness to use or operate (Rohmatan, 2016). The data yield showed the developed Moodle got positive response from teachers and students. It was said that the product help the learning process and attracted the attention of students in learning activities.

The effectiveness was measured based on the achievement of learning objectives. The more the learning objectives achieved, the more effective the media, and vice versa

Bioedukasi Vol. XVI. No. 2 Oktober 2018 
(Wang, 2012). Effectiveness can also be measured methodologically using action research (Mumtahanah, 2012).

Before conducting action research, the researcher prepare assessment instruments, and Learning Implementation Plan (RPP). The average pretest score was 60,9 (low), while the average post test score was 83,1 (high). The value of Normalized Gain was 0,545 or in intermediate level. Those data were obtained from SMAN 2 Purwoharjo. Result from SMAN 1 Purwoharjo showed that the average pre-test score was 66,7 (low), the average post-test score was 85,1 (high), and the normalized gain value was 0,523 (intermediate category).

Some observable factors that affecting the value of normalized gain were unpredicted technical problems during the implementation such as power failure, unfavorable schedule (at noon right after sport lesson). The improvement of student achievement is because students play roles in finding information related to the material, such as observing or practicing. This minds on activities lead to the effectiveness of the developed product (Kurniawan, 2015).

Broadly speaking, media web-based teaching materials using Moodle application are eligible to serve as an additional media materials, especially Fungi. Teaching materials can also be used as additional media other than books and worksheets that can be read before entering the learning activities as literacy activities.

This can provide students with attractive reading materials and enhance students' to learning activities. In addition, the media can also be used by students outside class that can add insight from students.

\section{CONCLUSION}

The web-based teaching materials of Fungi using Moodle learning applications has an average yield of $80.23 \%$ with very valid category ,

\section{SUGGESTION}

For high school teachers, teaching materials are expected to use web-based learning application such as Moodle. This platform provide an alternative source of learning in teaching and learning activities, as well as serve as an innovation and learning media to minimize the boredom of students during the learning process. For other researchers, web-based teaching materials Fungi using Moodle application for high school biology teaching can be developed more broadly in other materials or use other digital platforms.

\section{REFERENCE}

Ketut, I. 2016. Improving the Quality of School Education In Human Resources Development Efforts. Journal of Quality Assurance.

Herayanti, L., Habibi. Problem Based Learning Model 2015. Assisted Computer Simulations To Improve Critical Thinking Skills Candidate of Physics Teachers. Journal of Physical Education and Technology (ISSN. 2407-6902). Ol 1 No. 1, January 2015.

Widi, CA 2015. Virtual Laboratory Development Highlights in Excretion System to Improve Student Motivation Class XI. Student Scientific articles 21015, 1 (1): 1-8.

Anjarwati, D., Winarno, A., and Churiyah M. (2016). Improving Learning Outcomes by Developing Instructional Media-Based Adobe Flash Professional CS 5.5 on Principles of Business Subject. Journal of Research and Method in Education, 6 (5), 1-6.

Irianti, N, P., Elita, F, G, S. 2017. Development of Media-Based Learning E-Learning Moodle Highlights In Class Circle VII SMP. Scientific Journal of Mathematics Education. Vol 5 No. 2, March 2017, p 122-130.

Fuaddunazmi, M., Herayanti, L., Habibi. 2017. Development of Physics Berbasi Moodle Learning Tool. Journal of Physical Education and Technology (ISSN. 2407-6902). Volume 3, No. 2, December 2017. 
Fitriany., M. Hasan., Musri. 2016. Development Activity Sheet Students (LKPD) To Improve Comprehension Problem Based Learning Activities Concepts and Creative Students In Buffer Solution. Journal of Science Education Indonesia. Vol 04, No. 02, pp 24-35, 2016.

Praise, KM, F. Gulo, and AR Ibrahim. 2014. Development of Interactive Multimedia for Learning Form Molecules in high school. Journal of Chemical Education. 1 (1): $59-65$

Matondang, Z. 2009. A Validity and Reliability Research Instruments. Journal Tabularas UNIMED PPS. Vol. 6. 1, June 2009.

Hanifah, Umi. 2014. Importance of Quality Textbook in Improving the Effectiveness of Learning Arabic. Tarbiyah Science Journal "At-Tajdid". Vol. 3 \# 1.

Rohmatan, NF 2016. Snake and Ladder Game Development For Media Enrichment Lesson On Basic Banking in SMK Mojoagung. Journal of Accounting Education: 4 (3): 1-6.

Hestari, S, E, Susantini, and L, Lisdiana. 2016. The validity, practicality, and effectiveness Media Learning Board Magnetic Material Movements In Gen. BioEdu. 5 (1): 7-13.

Wang, TJ 2012. Educational Benefits of Multimedia Skills Training. TechTrends. 54 (1): 47-57.

Mumtahanah, N. 2014. Use of Visual Media in Learning PAI AL-HIKMAH. Journal of Islamic Studies, 4 (1): 91-104

Kurniawan, AD 2013. Guided Inquiry Methods in Learning Media Creation Biology to Improve Creativity Concept Training and Junior High School Students. Journal of Science Education Indonesia (JPII). 2 (1): 8-11.

Bioedukasi Vol. XVI. No. 2 Oktober 2018 